\title{
The effect of drying and ensiling grass on its digestion in sheep
}

\author{
Sites of energy and carbohydrate digestion
}

\author{
By D. E. BEEVER, * D. J. THOMSON*, E. PFEFFER†, \\ AND D. G. ARMSTRONG \\ Department of Agricultural Biochemistry, University of Newcastle upon Tyne
}

(Received I9 March 1970-Accepted 2 December 1970)

\begin{abstract}
I. The effect of drying and ensiling ryegrass on the site of digestion of the energy and carbohydrate fractions was studied in sheep fitted with rumen cannulas and re-entrant cannulas in the proximal duodenum and terminal ileum.

2. The sheep were given fresh (frozen) grass, dried grass, wilted and unwilted silage prepared from herbage harvested from the same sward. The grass diets were offered twice daily to each animal and paper impregnated with chromium sesquioxide was administered twice daily into the rumen. Twenty-four hour collections of duodenal and ileal digesta, adjusted to give $100 \%$ recovery of $\mathrm{Cr}_{2} \mathrm{O}_{3}$, were analysed to determine the extent of digestion in the forestomachs, the small intestine and the caecum and colon.

3. Total digestibility of the gross energy was similar for the fresh grass, dried grass and wilted silage diets $(67 \cdot 4,68 \cdot 1$ and $67.5 \%)$ but higher for the unwilted silage $(72 \cdot 0 \%, P<0.01)$. There was an increased flow of energy into the small intestine when the sheep were given dried grass and unwilted silage. The proportion of the apparently digested energy lost within the small intestine was greater when the dried grass was given $(30.2 \%)$ than when the fresh grass was given $(23.6 \%)$.

4. Drying or ensiling of wilted material affected digestion neither in the entire alimentary tract nor in the different sections of the tract, of some carbohydrate fractions. About $97 \%$ of the digested water-soluble carbohydrate, over $90 \%$ of the digested cellulose and over $70 \%$ of the digested hemicellulose were digested before reaching the small intestine. The increased amount of energy entering the duodenum of the sheep given the dried grass was not accounted for by changes in the fate of these carbohydrate fractions in the digestive tract. With unwilted silage, digestibilities of the cellulose and hemicellulose fractions were higher, and lower proportions of the digested carbohydrates were lost before the small intestine.
\end{abstract}

The effect of drying herbage on its nutritive value has been examined in calorimetric experiments by Graham (1964) and Ekern, Blaxter \& Sawers (1965a) and Schoch, Schürch \& Crasemann (1965). Other studies by Christian \& Williams (1957) and Prabucki \& Crasemann (I96I) have examined the digestion of fresh and dried herbage in the rumen.

Drying has been shown to depress the apparent digestibility of nitrogen in the herbage (Dijkstra, 1956; Graham, 1964; Ekern et al. 1965a). Differences between the results of Graham (1964) and Ekern et al. $(1965 a)$ as to the effect of drying herbage on the loss of energy as urine, as methane, and in the efficiency of utilization of the metabolizable energy of fresh and dried grass may have been due to the different diets used and the drying conditions imposed. Ekern et al. (1965a) harvested herbage from a mixed grass sward between May and October, dried for $\mathrm{II} h$ at $100^{\circ}$, and found higher losses of energy in the faeces and urine but lower losses as methane for sheep

* Present address: The Grassland Research Institute, Hurley, Maidenhead, Berks.

$\uparrow$ Present address: University of Göttingen. 
fed on dried grass compared with the corresponding fresh grass. The efficiency of utilization of the metabolizable energy for fattening was $50.4 \%$ for fresh grass and $55.4 \%$ for dried grass. Graham (1964) harvested herbage daily over a period of 3 months from a Paspalum grass and white clover sward, in which the ratio of grass to clover varied from $0 \cdot 6: 1$ to $I \cdot 2: 1$, and dried the herbage by sun-curing or with heat at $80^{\circ}$. Losses of energy from the dried grass in the faeces and as methane were higher than those measured with the fresh grass; the metabolizable energy of the dried herbage was utilized with an efficiency similar to that of the fresh herbage.

The nature and extent of digestion of fresh and dried herbage appear to be different. Technical advances in artificial drying as a method of conservation or as a necessary operation before processing (Raymond, 1969) suggest that further study of the effect of drying on the nutritive value of herbage is merited. Herbage may also be conserved by ensiling the crop directly after cutting (unwilted), or after a period of wilting. The fermentation occurring during the ensiling process results in a ruminant feed differing in several respects from the original fresh herbage and also from dried herbage.

We have therefore examined the effect of drying and ensiling on the sites of digestion within the alimentary tract using sheep that had been fitted with re-entrant cannulas. A single species of grass, S. 24 perennial ryegrass (Lolium perenne), was given to the sheep fresh (frozen), dried, as unwilted and wilted silage, and the quantitative digestion of the energy and carbohydrate fractions was studied. A preliminary report of the work on fresh and dried herbage has been published (Beever, Thomson, Pfeffer \& Armstrong, 1969).

\section{EXPERIMENTAL}

\section{Sheep}

Four mature Suffolk $\times$ Halfbred wethers, 2-3 years old and weighing $45-50 \mathrm{~kg}$, were used. Each was fitted with a rumen cannula, and with re-entrant cannulas at both the proximal duodenum and terminal ileum, by the technique of Brown, Armstrong \& MacRae (1968).

\section{Management of animals}

During the four experimental periods, the sheep were housed in metabolism crates in a controlled environment with $14 \mathrm{~h}$ illumination per day and an ambient temperature of $13-16^{\circ}$. All animals were given access to exercise pens with slatted floors when not on experiment.

The animals were fed at 09.00 and 16.00 hours, when equal amounts of food were offered. At each meal, a weighed amount of paper impregnated with chromium sesquioxide (Corbett, Greenhalgh, McDonald \& Florence, 1960) was administered via the rumen fistula ( $3 \mathrm{~g}$ per pellet). This was continued throughout the experimental period and for a period of at least $\mathrm{I} 4 \mathrm{~d}$ before the collection of any samples. Food refusals were recorded at the morning meal when they were removed. Distilled water was available at all times and consumption was recorded daily. 


\section{Preparation of diets}

All diets used in this study were prepared from an S. 24 ryegrass re-growth in the last week of June 1967 . Half of the crop was cut with a flail mower and chopped immediately into lengths of about $6 \mathrm{~cm}$. After harvesting, a rapid determination was made of the dry-matter content of the grass, and equal quantities of fresh material were weighed out to contain a calculated $900 \mathrm{~g}$ dry matter each. Some of these quantities were transferred directly into cloth sacks and subjected to blast-freezing at $-2 \mathrm{I}^{\circ}$ for $48 \mathrm{~h}$. The remainder were individually spread out on large trays, dried in a forced-draught oven at $100^{\circ}$ for $18 \mathrm{~h}$ (Grassland Research Institute, I96I), transferred to paper bags and finally stored. The remainder of the same ryegrass crop was used to prepare two silage diets. Unwilted silage was made by cutting, chopping and ensiling the crop directly in a small butyl rubber silo bag. For the other silage the cut crop was wilted overnight in the field and similarly ensiled after chopping. The silo bags were not evacuated. The two silos were opened 9 months later and half-day feeds of $45^{\circ} \mathrm{g}$ dry matter were weighed into polyethylene bags. All feeds were subsequently stored in a cold store at $-15^{\circ}$ until required.

The fresh and dried grasses were offered to the sheep directly from the deep-freeze; each bag comprising I day's food was accurately divided between the two meals before the 09.00 feed, and the portion to be offered at 16.00 hours was returned to the cold store until required. Each bag of ensiled material comprised one half-day's food and it was allowed to thaw for a period of 8-ro h before feeding.

\section{Collection of samples}

The collection of faeces and the $24 \mathrm{~h}$ collection of duodenal and of ileal digesta were as described by MacRae \& Armstrong (1969) with a few modifications. The daily samples of faeces obtained during the $7 \mathrm{~d}$ digestibility trial were accumulated on a wetmatter basis and the accumulated samples were used for all subsequent analyses. The accumulation of the individual samples of digesta for each animal was on a wet-matter basis as work in this laboratory (Beever, I969) showed this method of accumulation to give results similar to those of a method of dry-matter accumulation used by MacRae $\&$ Armstrong ( 1969 ). Sampling of the wet digesta (ileal or duodenal) for the preparation of $24 \mathrm{~h}$ cumulative samples for each sheep involved the use of a core sampling procedure developed in this laboratory by Unsworth (I970) (see Fig. I).

When digesta are ready to sample, they are first weighed (by difference) to the nearest $0^{\circ} \mathrm{I} g$ and then homogenized for $3 \mathrm{~min}$ in a Kenwood mixer (KNM 6 model; Kenwood Manufacturing (Woking) Ltd). The digesta is then transferred to a polyethylene cylinder with bung $A$ in position, but the glass tube withdrawn. A large rubber bung is inserted at the upper end and the whole cylinder inverted ten times by hand. The top bung is removed, the glass rod with its attached metal disc inserted and the end of the glass rod firmly seated into the recess on the lower large rubber bung. The receptor holding the sample being accumulated is then placed below the cylinder, bung $A$ is neatly removed with a pair of tongs and the digesta held within the glass tube are allowed to drain into the receptor. Use of a wide-mouthed $(9 \cdot 5 \mathrm{~cm} \mathrm{diam}$.) I 1 
polyethylene receptor prevents loss of digesta by splashing during the transfer; it also enables the sample being accumulated to be stored during and after collection in the deep-freeze.

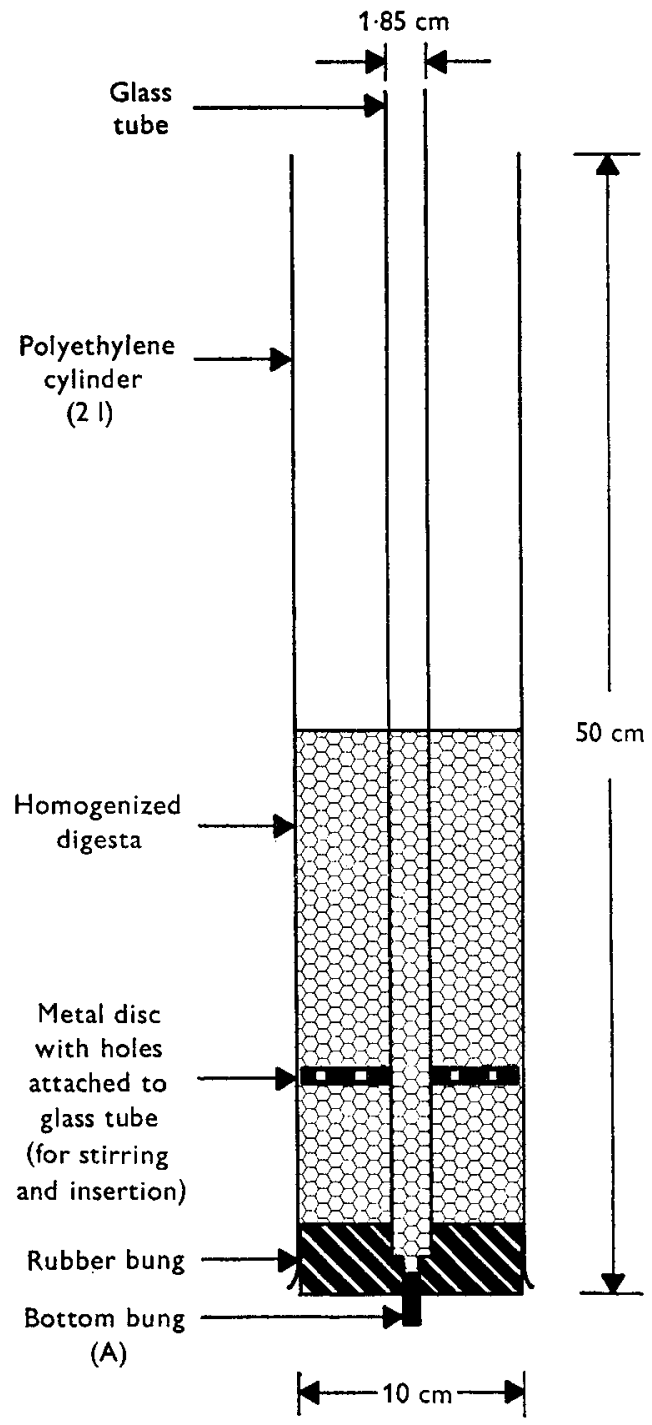

Fig. r. A diagrammatic representation of the sampling device used for obtaining wet accumulated sample of duodenal and ileal digesta (approximate sizes shown in $\mathrm{cm}$ ).

As the flow of ileal digesta was generally low and infrequent, the total output of each animal was sampled every $2-3 \mathrm{~h}$ during the $24 \mathrm{~h}$ period. The duodenal digesta were sampled every I-I.5 h or on the production of 500-600 $\mathrm{g}$ fresh digesta, whichever occurred first.

Several samples of rumen liquor were taken $3 \mathrm{~d}$ later on the two grass diets only, the same two sheep being sampled on each diet at $08.3^{\circ}, 10.3^{\circ}, 12.3^{\circ}$ and 14.30 hours. The 
samples were withdrawn by suction through a rumen cannula, strained through butter-muslin and $25 \mathrm{ml}$ of the liquor were deproteinized with $5 \mathrm{ml} 5 \mathrm{~N}-\mathrm{H}_{2} \mathrm{SO}_{4}$ saturated with $\mathrm{MgSO}_{4}$. After filtering, the samples were kept in the deep-freeze until required for analysis.

\section{Analysis of samples}

Samples of faeces and of digesta were thoroughly mixed before subsampling and subsequent drying of a small portion under reduced pressure at $40^{\circ}$. All vacuum-dried samples were then ground through a I mm sieve in a Christy \& Norris hammer-mill before analysis. Representative samples of the fresh grass and the two silages, taken during the process of weighing out of the diets, were freeze-dried immediately and then ground, whilst a representative sample of the dried-grass diet was ground after oven-drying at $100^{\circ}$ for $\mathrm{I} 8 \mathrm{~h}$.

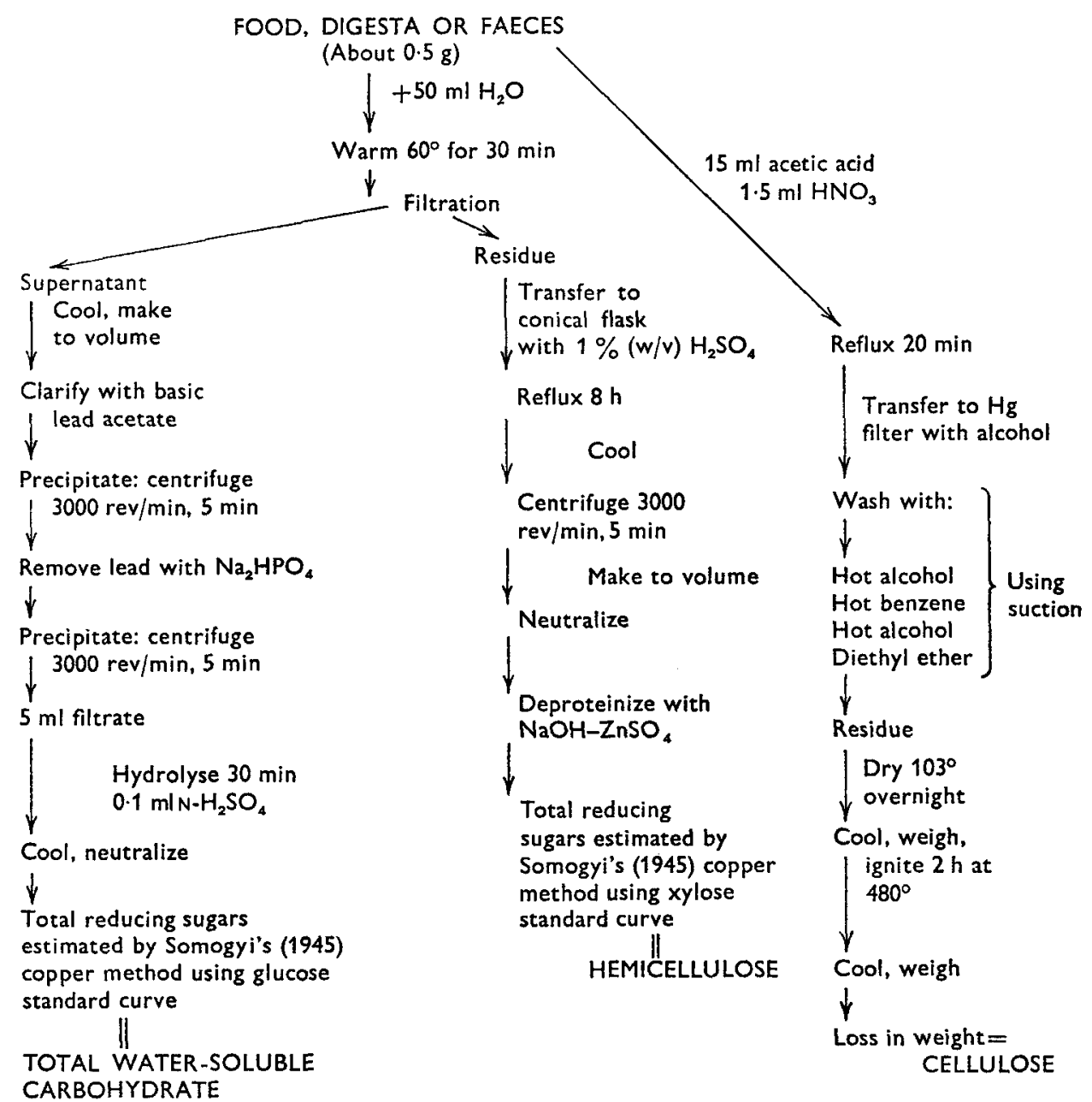

Fig. 2. Scheme of analysis adopted for the carbohydrate fractions of food, digesta and faecal samples. 
The residual moisture content of each sample was determined before the following determinations were made: gross energy (adiabatic bomb calorimeter; A. Gallenkamp \& Co. Ltd, London), chromic oxide content (Stevenson \& de Langen, I 960) and total nitrogen (macro-Kjeldahl). In addition, a scheme of analysis for the carbohydrate fractions was devised (see Fig. 2), and all samples were examined for total watersoluble carbohydrate (extraction with water for $30 \mathrm{~min}$ at $60^{\circ}$ and estimated colorimetrically (Somogyi, r 945)), hemicellulose (hydrolysis with $0.36 \mathrm{~N}-\mathrm{H}_{2} \mathrm{SO}_{4}$ for $8 \mathrm{~h}$ at $100^{\circ}$ on residue) and cellulose content (Crampton \& Maynard, 1938).

The rumen liquor samples were analysed for concentration of total volatile fatty acid (VFA) and molar proportions of VFA on a Pye I04 gas-liquid chromatograph equipped with a flame-ionization detector and a 'phase-sep' universal support coated with carbowax $20 \mathrm{M}$ terminated with terephthalic acid (R. F. Wilson, unpublished observations). In addition, the two fresh-silage diets were analysed for dry-matter content (toluene distillation, Dewar \& McDonald, $\mathrm{I}$ 96r), $\mathrm{pH}$ value, acetic, propionic and butyric acid content using a Pye 104 gas-liquid chromatograph (as described above) and lactic acid content (Elsden \& Gibson, 1954).

\section{Calculation of results}

All values relating to duodenal and ileal flows are corrected to mean $24 \mathrm{~h}$ values on the basis of $100 \%$ recovery of chromic oxide, as proposed by MacRae \& Armstrong (1969). The information presented about the sites of digestion of the two grasses relates to three sheep with the exception of that about quantities of nutrients passing the terminal ileum of sheep given dried grass, which is the mean for two sheep only. One of the three animals refused small amounts of food on each diet throughout both experimental periods, large refusals by this animal towards the end of the dried-grass feeding regimen prevented the collection of the required ileal sample and, with a limited quantity of surplus feed available, it was not possible to repeat the experiment. No rumen liquor samples were taken from this animal for either of the grass diets.

The wilted-silage diet was offered to the same three sheep; two of these animals left large amounts uneaten. An additional animal, with similar surgical modifications, was brought into the experiment and the results relating to both the silage diets are the mean for two animals only. In addition, one of these animals began to refuse large quantities of unwilted silage before the collection of duodenal digesta was made; thus the quantities of nutrients passing the proximal duodenum of the sheep given unwilted silage relate to one animal only.

\section{RESULTS}

Table I shows the chemical composition of the four diets used. A comparison of the fresh and dried grass shows that the drying process had little effect on the composition of the two diets, although the dried grass had a slightly higher total nitrogen content. In contrast, the two silage diets had lower total water-soluble carbohydrate and slightly increased total nitrogen contents. The fresh and dried grasses and the wilted silage had a mean calorific value of $4.53 \mathrm{kcal} / \mathrm{g}$ dry matter; the value for unwilted silage was 4.89 . 
Table 2 shows the composition of the wilted and unwilted-silage diets with respect to dry matter and organic acid contents and $\mathrm{pH}$. The dry-matter contents reflect the two harvesting treatments imposed, and the unwilted silage had a higher acid content and lower $\mathrm{pH}$ value than the wilted silage.

\begin{tabular}{|c|c|c|c|c|}
\hline Constituent & $\begin{array}{l}\text { Fresh } \\
\text { grass }\end{array}$ & $\begin{array}{c}\text { Dried } \\
\text { grass }\end{array}$ & $\begin{array}{l}\text { Wilted } \\
\text { silage }\end{array}$ & $\begin{array}{l}\text { Unwilted } \\
\text { silage }\end{array}$ \\
\hline Organic matter & $90 \cdot 8$ & $92 \cdot 0$ & $92 \cdot 2$ & $9 \mathrm{I} \cdot 7$ \\
\hline $\begin{array}{l}\text { Total water-soluble } \\
\text { carbohydrate }\end{array}$ & $9 \cdot 2$ & $8 \cdot 4$ & $\mathrm{TR}$ & TR \\
\hline Cellulose & $24 \cdot 2$ & $24 \cdot 3$ & $25^{\circ} 0$ & $26 \cdot 8$ \\
\hline Hemicellulose & I4.O & $13 \cdot 3$ & $12 \cdot 9$ & $13 \cdot 1$ \\
\hline Total nitrogen & $2 \cdot 85$ & $2 \cdot 99$ & 3.09 & 3.08 \\
\hline Gross energy (kcal/ & 4.59 & 4.55 & 4.46 & $4 \cdot 89$ \\
\hline
\end{tabular}

TR, trace.

Table 2. Composition of organic acids present in the two silage diets (all concentrations expressed as $\mathrm{g} / \mathrm{I} 00 \mathrm{~g}$ dry matter)

$\begin{array}{lcc} & \begin{array}{c}\text { Wilted } \\ \text { silage }\end{array} & \begin{array}{c}\text { Unwilted } \\ \text { silage }\end{array} \\ \text { Dry-matter content } & 36.2 & 18.5 \\ \text { Acetic acid } & 0.5 & 4.8 \\ \text { Propionic acid } & 0.1 & 0.2 \\ \text { Butyric acid } & 0.3 & 0.6 \\ \text { Lactic acid } & 5.2 & 10.5 \\ \text { pH value } & 4.5 & 3.9\end{array}$

The daily quantities of gross energy $(\mathrm{kcal} / 24 \mathrm{~h})$ present in the food and faeces and passing at the proximal duodenum and terminal ileum are shown in Table 3 . In addition (as with Tables 4, 5 and 6), the apparent digestibility of the gross energy and the contribution of the different digestive sites to total digestion are shown. At the level of feeding used in this experiment the drying process had no effect on the apparent digestibility of the gross energy fraction of the grass (fresh, $67 \cdot 4 \%$; dried, $68 \cdot 1 \%$ ). The wilted silage had a similar value $(67 \cdot 5 \%)$, but the higher calorific value of the unwilted silage contributed to higher apparent energy digestibility $(72 \cdot 0 \%)$ for this diet. The mean value recorded for unwilted silage was significantly higher $(P<0.05)$ than those for the other three diets. Consideration of the sites of disappearance of the apparently digestible energy fraction reveals the dried grass and unwilted silages to have markedly reduced losses of this fraction within the reticulo-rumen (dried grass, $53.4 \%$; unwilted silage, $56 \cdot 8 \%$ ). With both these diets increased quantities of energy entered the small intestine ( $12 \%$ of that observed for fresh grass and wilted silage). However, the mean values for percentage loss of apparently digestible energy occurring within the reticulo-rumen were not significantly different $(P>0.05)$. A previous comparison of the values for fresh and dried grass only had shown the difference between these two diets to be significant at the $5 \%$ level of probability.

The changes in the flow of energy through the alimentary tract of sheep fed on 
either dried grass or unwilted silage indicated a greater net loss of apparently digestible energy in the small intestine on these diets $(847$ and $1100 \mathrm{kcal} / 24 \mathrm{~h})$, than on the fresh grass and wilted silage $(657$ and $738 \mathrm{kcal} / 24 \mathrm{~h}$ ). At the terminal ileum the flows of energy on the fresh grass and dried grass were very similar, I 721 and $1767 \mathrm{kcal}$ respectively, and for the wilted and unwilted silages 1594 and $1565 \mathrm{kcal} / 24 \mathrm{~h}$. Less energy was digested in the caecum and colon of sheep given the silage diets (mean value $300 \mathrm{kcal} / 24 \mathrm{~h}$ ) than in those receiving the grass diets (mean value $416 \mathrm{kcal} / 24 \mathrm{~h}$ ).

In an attempt to identify the substrates giving rise to the changes in energy flow, the carbohydrate fraction was analysed, as illustrated in Fig. 2.

Table 3. Mean quantities of gross energy present in the food, entering and leaving the small intestine and in the faeces of sheep given fresh grass, dried grass, wilted and unwilted silage

\begin{tabular}{|c|c|c|c|c|}
\hline & $\begin{array}{l}\text { Fresh } \\
\text { grass }\end{array}$ & $\begin{array}{r}\text { Dried } \\
\text { grass }\end{array}$ & $\begin{array}{c}\text { Wilted } \\
\text { silage }\end{array}$ & $\begin{array}{l}\text { Unwilted } \\
\text { silage }\end{array}$ \\
\hline \multicolumn{5}{|l|}{ Gross energy $(\mathrm{kcal} / 24 \mathrm{~h})$ : } \\
\hline In food & 4136 & 4112 & 3977 & 4510 \\
\hline At proximal duodenum & 2378 & 2614 & $233^{2}$ & $2665^{*}$ \\
\hline At terminal ileum & I 721 & I $767 \dagger$ & 1594 & 1565 \\
\hline In faeces & 1347 & 1310 & 1294 & $\times 265$ \\
\hline $\begin{array}{l}\text { Apparent digestibility of } \\
\text { gross energy }(\%)\end{array}$ & $67 \cdot 4 \pm 1 \cdot 7$ & $68 \cdot 1 \pm \mathbf{I} \cdot 2$ & 67.5 & $72 \cdot 0$ \\
\hline \multicolumn{5}{|l|}{$\begin{array}{l}\text { Disappearance of apparently } \\
\text { digested energy }(\%) \text { : }\end{array}$} \\
\hline Before small intestine & $63 \cdot 0 \pm 0 \cdot 3$ & $53 \cdot 4 \pm 2 \cdot I$ & $6 r \cdot 4$ & 56.8 \\
\hline In small intestine & $23 \cdot 6 \pm 2 \cdot 0$ & $30 \cdot 2$ & $27 \cdot 4$ & 33.9 \\
\hline In caecum and colon & $13 \cdot 4 \pm 2 \cdot 2$ & $16 \cdot 3$ & $r i \cdot 2$ & $9 \cdot 3$ \\
\hline
\end{tabular}

The mean total water-soluble carbohydrate content of the fresh grass was $9 \cdot 2 \%$, and from Table I it can be seen that drying resulted in a slight reduction in this value. The effect of ensiling the grass was most noticeable, with only traces of water-soluble carbohydrate present in both silage diets. The results given in Table 4 illustrate the digestive fate of the total water-soluble carbohydrate fraction of the fresh-grass and dried-grass diets. On both diets total digestion was $100 \%$; only small quantities of water-soluble carbohydrate escaped rumen fermentation and entered the small intestine.

The digestive fate of the cellulose fraction is shown in Table 5. The apparent digestibility of this fraction was unaffected by drying but was 5 digestibility units higher $(P<0.05)$ for the cellulose contained in the unwilted silage $(80.6 \%)$ than for that present in the three other diets $(75.7 \%)$. More cellulose was consumed by sheep given unwilted silage and quantitatively more digested before the small intestine, but mean values for proportionate digestion in the fore-stomach $(9 \mathrm{r} \%)$ and the caecum and colon $(9 \%)$ were very similar for all diets.

Results for the digestion of the hemicellulose fraction are presented in Table 6 . 
Total digestibility of the hemicellulose fraction was similar in the fresh-grass, driedgrass and wilted-silage diets (mean $59.0 \%$ ) but slightly higher for the unwilted silage $(63.2 \%)$. There appeared to be little difference between the diets in terms of hemicellulose digestion. In all diets digestion in the caecum and colon appeared to make a considerable contribution to total hemicellulose digestion. Mean values for proportionate digestion in the fore-stomach and the caecum and colon were $70 \%$ and $30 \%$ respectively.

\section{Table 4. Mean quantities of total water-soluble carbohydrate present in the food, entering} and leaving the small intestine and in the faeces of three sheep given fresh or dried grass

(The values for digesta at the duodenum and ileum have been adjusted for $100 \%$ recovery of chromic oxide. Mean values (with standard errors where stated) for the disappearance of apparently digested water-soluble carbohydrate before and in the small intestine and in the caecum and colon are also given)

$\begin{array}{lcc} & \text { Fresh } & \text { Dried } \\ \text { Water-soluble carbohydrate } & & \\ \text { (g/24 h): } & & \\ \text { In food } & 82 \cdot 8 & 75 \cdot 8 \\ \text { At proximal duodenum } & \mathrm{I} \cdot 5 & 2 \cdot 6 \\ \text { At terminal ileum } & 0.6 & \mathrm{I} \cdot \mathrm{I}^{*} \\ \text { In faeces } & \text { None } & \text { None } \\ \text { Apparent digestibility of water- } & \text { Ioo } & \text { I00 } \\ \text { soluble carbohydrate (\%) } & & \\ \text { Disappearance of apparently } & & \\ \text { digestible water-soluble } & & \\ \text { carbohydrate (\%): } & & \\ \text { Before small intestine } & 98 \cdot 2 \pm 0.4 & 96 \cdot 6 \pm 0 \cdot \mathrm{I} \\ \text { In small intestine } & \mathrm{I} \cdot \mathrm{I} \pm 0 \cdot 2 & 2 \cdot 0 \\ \text { In caecum and colon } & 0.8 \pm 0 . \mathrm{I} & \mathrm{I} \cdot 4\end{array}$

* Mean for two animals only.

Table 5. Mean quantities of cellulose present in the food, entering and leaving the small intestine and in the faeces of sheep given fresh grass, dried grass, wilted or unwilted silage

(The values for digesta at the duodenum and ileum have been adjusted for $100 \%$ recovery of chromic oxide. Mean values (with standard errors where stated) for the disappearance of digestible cellulose before and in the small intestine and in the caecum and colon are also shown)

\begin{tabular}{|c|c|c|c|c|}
\hline & $\begin{array}{l}\text { Fresh } \\
\text { grass }\end{array}$ & $\begin{array}{l}\text { Dried } \\
\text { grass }\end{array}$ & $\begin{array}{l}\text { Wilted } \\
\text { silage }\end{array}$ & $\begin{array}{l}\text { Unwilted } \\
\text { silage }\end{array}$ \\
\hline \multicolumn{5}{|l|}{ Cellulose $(\mathrm{g} / 24 \mathrm{~h})$ : } \\
\hline In food* & $222 \cdot 9$ & 223.7 & $229 \cdot 3$ & 253.5 \\
\hline At proximal duodenum & $66 \cdot I$ & $68 \cdot 8$ & $64 \cdot 2$ & $75 \cdot 1 \dagger$ \\
\hline At terminal ileum & $72 \cdot 9$ & $68 \cdot 2 t$ & 69.4 & $68 \cdot I$ \\
\hline In faeces & $55 \cdot 3$ & $54 \cdot 7$ & $53 \cdot 9$ & $49 \cdot 3$ \\
\hline $\begin{array}{l}\text { Apparent digestibility of } \\
\text { cellulose }(\%)\end{array}$ & $75^{\cdot 2} \pm \mathrm{r} \cdot 8$ & $75 \cdot 5 \pm I \cdot 9$ & $76 \cdot 5$ & $80 \cdot 6$ \\
\hline \multicolumn{5}{|l|}{$\begin{array}{l}\text { Disappearance of digestible } \\
\text { cellulose }(\%) \text { : }\end{array}$} \\
\hline Before small intestine & $93 \cdot 6 \pm 2 \cdot 0$ & $9 I \cdot 7 \pm 2 \cdot I$ & $94^{\prime} I$ & $87 \cdot 4$ \\
\hline In small intestine & $4 \cdot 1 \pm 4 \cdot 3$ & 0.0 & $2 \cdot 9$ & 3.4 \\
\hline In caecum and colon & $10.5 \pm 2.4$ & $8 \cdot 3$ & $8 \cdot 8$ & $9 \cdot 2$ \\
\hline
\end{tabular}

* Includes $6 \mathrm{~g}$ administered with chromic oxide pellet.

+ Observation for one animal only.

$\ddagger$ Mean for two animals only. 
The proportions of volatile fatty acids in the rumen liquor of two sheep given fresh and dried grass are shown in Table 7 . No comparable values for the silage diets are available. The results indicate a lower proportion of acetic acid and a higher proportion of the branched-chain fatty acids in the rumen liquor of sheep given fresh grass; the proportions of propionic acid were very similar for both diets.

Table 6. Mean quantities of hemicellulose present in the food, entering and leaving the small intestine and in the faeces of sheep given fresh grass, dried grass, wilted or unwilted silage

\begin{tabular}{|c|c|c|c|c|}
\hline & $\begin{array}{l}\text { Fresh } \\
\text { grass }\end{array}$ & $\begin{array}{l}\text { Dried } \\
\text { grass }\end{array}$ & $\begin{array}{l}\text { Wilted } \\
\text { silage }\end{array}$ & $\begin{array}{l}\text { Unwilted } \\
\text { silage }\end{array}$ \\
\hline \multicolumn{5}{|l|}{ Hemicellulose $(g / 24 h):$} \\
\hline In food & $120 \cdot 7$ & I 15.4 & I I $4 \cdot 8$ & $I 2 I \cdot I$ \\
\hline At proximal duodenum & $66 \cdot 8$ & $67 \cdot 3$ & $67 \cdot 8$ & $72 \cdot 7^{*}$ \\
\hline At terminal ileum & $66 \cdot 9$ & $7 x \cdot 6 \dagger$ & $67 \cdot 6$ & $65 \cdot 6$ \\
\hline In faeces & $49 \cdot 0$ & $48 \cdot 8$ & $46 \cdot 0$ & $44 \cdot 6$ \\
\hline $\begin{array}{l}\text { Apparent digestibility of } \\
\text { hemicellulose }(\%)\end{array}$ & $59.4 \pm 4.0$ & $57 \cdot 7 \pm 3 \cdot 4$ & $59^{\circ} 9$ & $63 \cdot 2$ \\
\hline \multicolumn{5}{|l|}{$\begin{array}{l}\text { Disappearance of digestible } \\
\text { hemicellulose }(\%) \text { : }\end{array}$} \\
\hline Before small intestine & $75^{\prime} \pm \pm 6 \cdot 4$ & $72 \cdot 2 \pm 2 \cdot 1$ & $68 \cdot 4$ & $63 \cdot 2$ \\
\hline In small intestine & $0 \cdot 1 \pm 1 \cdot 7$ & $6 \cdot 5$ & 0.2 & $9 \cdot 3$ \\
\hline In caecum and colon & $25 \cdot 0 \pm 5 \cdot 2$ & $34 \div 3$ & $31 \cdot 4$ & $27 \cdot 5$ \\
\hline
\end{tabular}

Table 7. Total volatile fatty acid concentrations ( $m$-mol/100 $m l)$ and proportions (molar \% basis) in the rumen liquor of sheep given fresh (frozen) or dried grass (mean values with their standard errors)

$\begin{array}{llcccccc}\text { Diet } & \text { Total } & \text { Acetic } & \text { Propionic } & \text { Isobutyric } & \text { Butyric } & \text { Isovaleric } & \text { Valeric } \\ \begin{array}{c}\text { Fresh } \\ \text { grass }\end{array} & 7.68 & 63.4 \pm 2 \cdot 3 & 22.1 \pm 2.1 & 1.7 \pm 0.2 & 10.0 \pm 0.7 & 2 \cdot 1 \pm 0.5 & 0.7 \pm 0.2 \\ \begin{array}{c}\text { Dried } \\ \text { grass }\end{array} & 8.65 & 67 \cdot 6 \pm 2.0 & 21 \cdot 8 \pm 1.5 & 1 \cdot 1 \pm 0.3 & 8.0 \pm 0.6 & 1 \cdot 3 \pm 0.5 & 0.5 \pm 0.1\end{array}$

\section{DISCUSSION}

The fresh grass used was prepared from a re-growth of S. 24 perennial ryegrass and it was preserved by freezing. Raymond, Harris \& Harker (1953) found no difference in the organic matter and nitrogen digestibility of herbage preserved by freezing when compared with the same herbage given fresh. Ekern, Blaxter \& Sawers (1965 $b$ ) compared fresh and frozen grass and showed that the losses of energy in the faeces, in the urine and as methane were similar. Although the energy retention of the animals given frozen grass was slightly higher than for those given fresh grass, this difference was not statistically significant. On the basis of these results it would appear as though total energy digestion of frozen herbage is similar to that of the fresh material. Whether 
frozen and fresh herbages are similar substrates as far as the digestive processes within particular sites of the digestive tract are concerned is less certain, although for the purposes of the following discussion this assumption has been made.

In the present experiment, at the plane of nutrition employed, drying at $100^{\circ}$ did not affect the apparent digestibility of the gross energy of the diet. Despite this similarity in total digestibility, drying did lead to an increase in the flow of gross energy into, and digestion within, the small intestine compared with the fresh grass (Table 3). The apparent digestibility of the gross energy of the wilted-silage diet was similar to that of the fresh- and dried-grass diets. The flow of energy through the alimentary tract and the site of digestion of the energy of the wilted-silage diet were more similar to those of the fresh grass than to those of any of the other experimental diets. The unwiltedsilage diet, however, differed in several respects from both the wilted-silage and the fresh-grass diets. The apparent digestibility of the gross energy of the unwilted silage was some 4 percentage digestibility units higher, owing primarily to the higher calorific value of the food per $g$ dry matter, and this resulted in a higher consumption of gross energy on that diet. This higher energy content of unwilted silage has previously been noted by Waldo, Miller, Okamoto $\&$ Moore (1965) for lucerne silage and by Thomson (1968) for grass silage. Harris, Raymond \& Wilson (I966) have also shown the digestibility of the dry matter in unwilted silage to be higher than of that in wilted silage over a range of different forage diets.

The flow of energy into the small intestine of sheep given the unwilted silage was $2665 \mathrm{kcal} / 24 \mathrm{~h}$ and at the terminal ileum $1565 \mathrm{kcal} / 24 \mathrm{~h}$. Proportionate digestion of energy in the fore-stomachs was less and in the small intestine greater on the unwilted than on the wilted silage. Quantitatively, the gross energy disappearing in the small intestine declined in the order unwilted silage (I roo kcal), dried grass $(847 \mathrm{kcal})$, wilted silage $\left(73^{8} \mathrm{kcal}\right)$ and fresh grass $\left(6_{57} \mathrm{kcal}\right)$.

Drying did not affect digestion, either in the entire alimentary tract or in different sections of the tract, of the three carbohydrate fractions studied. Digestion in the forestomachs accounted for approximately $100 \%$, over $90 \%$, and over $70 \%$ of the digestible water-soluble carbohydrate, cellulose and hemicellulose fractions respectively. Digestion in the caecum and colon was of significance only for the hemicellulose fraction. Thus the greater amount of energy entering the duodenum of the sheep given dried grass, compared with fresh grass, could not be accounted for by changes in the digestion of the carbohydrate fractions. However, the rates of fermentation in the rumen of the carbohydrate and protein fractions of the fresh and dried diets may have been different. When grass dried at $100^{\circ}$ was used, Ekern et al. ( $\left.1965 a\right)$ found methane production to be lower than when the grass was given fresh. Heat-drying also probably led to denaturation and reduced solubility of the herbage protein. In the present experiment a higher proportion of branched-chain fatty acids was present in the rumen of the sheep given fresh grass (Table 7), indicative of more extensive degradation of herbage protein within the rumen.

In this experiment, as in others (Watson, I939; Dijkstra, 1956; Graham, I964; Ekern et al. $1965 a$ ), drying of herbage depressed the apparent digestibility of nitrogen (fresh, $75.0 \%$; dried $7 \mathrm{I} \cdot \mathrm{I} \%$ ). An increased flow of nitrogen into the small intestine of 
the sheep given dried grass was observed (Beever et al. r969), compared with the amount ingested and with the amount entering the small intestine of the sheep given fresh grass. Depending on the temperature and duration of drying, and on the nature of the herbage protein, drying may reduce the solubility of herbage protein, depress the rate of proteolysis in the rumen and increase the net synthesis of microbial protein (and energy) in the rumen of sheep given dried grass.

One of us (D.J.T.) was on secondment from the Grassland Research Institute, Hurley.

\section{REF EREN CES}

Beever, D. E. (1969). Sites of digestion in the adult sheep, of carbohydrates in forage and cereal diets. $\mathrm{PhD}$ Thesis, University of Newcastle upon Tyne.

Beever, D. E., Thomson, D. J., Pfeffer, E. \& Armstrong, D. G. (I969). Proc. Nutr. Soc. 28, 26 A.

Brown, G. F., Armstrong, D. G. \& MacRae, J. C. (I 968). Br. vet. F. r24, 78.

Christian, K. R. \& Williams, V. J. (I957). N.Z. Fl Sci. Technol. A 38, roo3.

Corbett, J. L., Greenhalgh, J. F. D., McDonald, I. \& Florence, E. (I960). Br. J. Nutr. 14, 289.

Crampton, E. W. \& Maynard, R. A. (1938). F. Nutr. 15, 383.

Dewar, W. A. \& McDonald, P. (r96r). F. Sci. Fd Agric. 12, 790.

Dijkstra, N. D. (1956), Landbouwvoorlichting r3, 223.

Ekern, A., Blaxter, K. L. \& Sawers, D. (1965a). Br. F. Nutr. 19, 417.

Ekern, A., Blaxter, K. L. \& Sawers, D. (1965b). Energy Metabolism p. 217 [K. L. Blaxter, editor]. London and New York: Academic Press.

Elsden, S. R. \& Gibson, Q. H. (I954). Biochem. 7. 58, I 54.

Graham, N. McC. (1964). Aust. F. agric. Res. 15, 974.

Grassland Research Institute (196I). Bull. Commonw. Bur. Past. Fld Crop no. 45.

Harris, C. E., Raymond, W. F. \& Wilson, R. F. (1966). Int. Grassld Congr. x. Helsinki p. 564.

MacRae, J. C. \& Armstrong, D. G. (r969). Br. F. Nutr. 23, I 5.

Prabucki, A. L. \& Crasemann, E. (I96r). Int. Congr. Anim. Prod. virr. Hamburg p. 34.

Raymond, W. F. (1969). Adv. Agron. 21, 2.

Raymond, W. F., Harris, C. E. \& Harker, V. G. (I953). F. Br. Grassld Soc. 8, 3 I 5.

Schoch, H., Schürch, A. \& Crasemann, E. (1965). Energy Metabolism p. 225 [K. L. Blaxter, editor]. London and New York: Academic Press.

Somogyi, M. (г945). F. biol. Chem. 160, 61.

Stevenson, A. E. \& de Langen, H. (1960). N.Z. Fl agric. Res. 3, 3 I4.

Thomson, D. J. (1968). Anim. Prod. ro, 240.

Unsworth, E. F. (1970). Some aspects of nitrogen digestion in the adult sheep. MSc Thesis, University of Newcastle upon Tyne.

Waldo, D. R., Miller, R. W., Okamoto, M. \& Moore, L. A. (I965). F. Dairy Sci. 48, gro.

Watson, S. J. (1939). The Science and Practice of Conservation: Grass and Forage Crops. London: The Fertilizer and Feedingstuffs Journal. 